\title{
Pentingnya Analisis Keuangan dalam Menjalankan Suatu Usaha
}

\author{
Alvin Cahya Wijaya \\ Program Studi Kewirausahaan \\ Universitas Bina Nusantara \\ alvin.wijaya010@binus.ac.id
}

Analisis keuangan adalah proses mengevaluasi bisnis, proyek, anggaran, dan transaksi terkait keuangan lainnya untuk menentukan kinerja dan kesesuaian mereka. Biasanya, analisis keuangan digunakan untuk menganalisis apakah suatu entitas stabil, likuid, atau cukup menguntungkan untuk menjamin investasi moneter. Hal ini dilakukan melalui sintesis angka dan data keuangan. Seorang analis keuangan akan benar-benar memeriksa laporan keuangan perusahaan, laporan laba rugi, neraca, dan laporan arus kas. Analisis keuangan dapat dilakukan baik dalam pengaturan keuangan perusahaan dan keuangan investasi. Salah satu cara paling umum untuk menganalisis data keuangan adalah dengan menghitung rasio dari data dalam laporan keuangan untuk dibandingkan dengan perusahaan lain atau terhadap kinerja historis perusahaan sendiri (Alicia, 2016). Karena semakin banyak orang membuat keputusan untuk mengendalikan kesopanan investasi mereka sendiri, kebutuhan penjelasan alat analisis keuangan menjadi lebih besar (Friedlob \& Schleifer, 2003).

Kesehatan keuangan adalah salah satu indikator terbaik dari potensi dalam pertumbuhan jangka panjang. Langkah pertama menuju peningkatan literasi keuangan adalah melakukan analisis keuangan bisnis. Analisis yang tepat terdiri dari lima bidang utama (Periu, 2019), yaitu:

1. Pendapatan

Pendapatan mungkin adalah sumber utama uang tunai bisnis. Kuantitas, kualitas dan waktu pendapatan dapat menentukan kesuksesan jangka panjang. Banyak perusahaan yang sangat sukses mencapai lebih dari \$ 1 juta dalam pendapatan tahunan per karyawan.

2. Keuntungan

Jika tidak dapat menghasilkan keuntungan berkualitas secara konsisten, bisnis tersebut mungkin tidak bertahan dalam jangka panjang. Inilah yang tersisa untuk reinvestasi ke dalam bisnis tersebut dan untuk distribusi kepada pemilik dalam bentuk dividen. 


\section{Efisiensi Operasional}

Efisiensi operasional mengukur seberapa baik perusahaan dalam menggunakan sumber daya perusahaan. Kurangnya efisiensi operasional menyebabkan keuntungan yang lebih kecil dan pertumbuhan yang lebih lemah.

4. Efisiensi Modal dan Solvabilitas

Efisiensi modal dan solvabilitas menarik bagi pemberi pinjaman dan investor. Leverage tidak boleh melebihi apa yang masuk akal untuk bisnis perusahaan tersebut.

5. Likuiditas

Analisis likuiditas membahas kemampuan perusahaan untuk menghasilkan uang tunai yang cukup untuk menutupi biaya tunai. Tidak ada jumlah pertumbuhan pendapatan atau keuntungan yang dapat mengimbangi likuiditas yang buruk.

Perencanaan keuangan erat kaitannya dengan proyeksi laba, laporan penjualan dan juga aktiva yang berpatokan kepada strategi produksi dan juga pemasaran serta meliputi penentuan sumber daya yang akan diperlukan dalam rangka sebagai usaha untuk mencapai proyeksi tersebut. Dalam melakukan proses perencanaan keuangan, manajer harus mengevaluasi rencana yang akan dilaksanakan serta mengidentifikasi perubahan-perubahan pada operasi agar dapat meningkatkan hasil yang akan dicapai oleh perusahaan (Purnomo, 2020). Angka-angka akan selalu berubah, tetapi pelajaran yang pasti akan dapat dipelajari melalui penyusunan pernyataan sangat berharga. Terkadang, pengusaha mengabaikan nilai analisis keuangan, berpikir bahwa angkaangka itu hanya tebakan sehingga mereka benar-benar tidak penting. Namun, menunjukkan kemampuan untuk menyiapkan laporan keuangan dan memikirkan masalah di baliknya sangat penting (Barringer, 2015).

\section{References}

Alicia, T. (2016). Financial Analysis Definition. Investopedia. http://www.investopedia.com/terms/f/financial-analysis.asp

Barringer, B. (2015). Preparing Effective Business Plans: An Entrepreneurial Approach (2nd ed.). Pearson Education Limited.

Friedlob, G. T., \& Schleifer, L. L. F. (2003). Essentials of Financial Analysis. Wiley.

Periu, M. (2019). What is Financial Analysis. American Express https://www.americanexpress.com/en-us/business/trends-andinsights/articles/financial-analysis-small-business-health/

Purnomo, A., Sudirman, A., Hasibuan, A., Sudarso, A., Sahir, S. H., Salmiah, Mastuti, R., Chamidah, D., Koryati, T., \& Simarmata, J. (2020). Dasar-Dasar Kewirausahaan: untuk Perguruan Tinggi dan Dunia Bisnis. Yayasan Kita Menulis. 


\section{Biografi}

\section{Alvin Cahya Wijaya}

Alvin Cahya Wijaya adalah seorang mahasiswa sedang menempuh pendidikan tinggi di sebuah perguruan tinggi Universitas Bina Nusantara pada program studi kewirausahaan sejak tahun 2020. Saat ini ia akan merintis start up bersama teman temannya.

E-mail: alvin.wijaya010@binus.ac.id

Instagram: @alvinwvi 